\title{
Preparation Of Future School Leaders
}

Lynn Walton Varner, (E-mail: lvarner@deltastate.edu), Delta State University

\begin{abstract}
An Educational Leadership program in the Mississippi Delta region has been recognized as one of the top eight programs in the country by an exhaustive national research study conducted by Stanford University.
\end{abstract}

\section{INTRODUCTION}

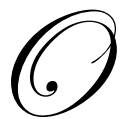

ne Educational Leadership preparation program in a rather unexpected location, the Mississippi Delta region, has received national recognition from the Educational Leadership Constituent Council, been asked to use its program report on the National Council for Accreditation of Teacher Education (NCATE) website as a national example of excellence, received the state award for Best Practices, and been recognized as one of the top eight programs in the country by an exhaustive national research study conducted by Stanford University. The key components of this program are presented in this paper.

\section{REVIEW OF LITERATURE}

Principals play a vital role in setting the direction for successful schools, but existing knowledge on the best ways to prepare and develop highly qualified candidates is sparse. For many years leadership preparation programs focused on a discrete group of managerial skills with little synthesis of the broad spectrum of attributes needed by the effective educational leader. More recent works in the field of leadership point out the effective behaviors needed to deal with the complexities of $21^{\text {st }}$ century schools. Glatter (2006) emphasized the importance of viewing schools and school districts as complex adaptive systems. Sousa (2003) noted that four broad needs should be considered for those who would provide leadership to schools: demonstrating support for change, establishing a vision and mission, ensuring strength in the role of building principals, and encouraging school board members to concern themselves with supporting change through strategic planning.

Drucker (1999) noted that school leaders should examine six aspects to determine their promise for leadership-their strengths, assessment of their prior performance, examination of their value systems, determination of the leadership positions that are most compatible with their skills and abilities, determination of the specific contributions that are realistic and achievable for themselves, and recognition of the importance of relationship building. As Warren Bennis (1994, p.40) so aptly put it “...Until you truly know yourself, strengths and weaknesses, know what you want to do and why you want to do it, you cannot succeed in any but the most superficial sense of the word. The leader never lies to himself...." Sousa $(2003$, p.17) further stated that effective leaders are "proactive, committed, and decisive individuals who are willing to take risks while looking for creative ways to solve problems." Bolman and Deal (1997, p. xii) also noted that "when organizations are over-managed but under-led, they eventually lose any sense of spirit." Additionally, Bolman and Deal (1997) emphasized that when the rational and technical side of organizations is overemphasized, decline or demise of the organization usually follows. Caruso and Salovey (2004) asserted that six core areas exist for leaders/managers - building effective teams, planning and deciding effectively, motivating people, communicating a vision, promoting change, and creating effective interpersonal relationships. Glickman (2002) indicated that instructional leaders should use the behaviors of listening, clarifying, encouraging, reflecting, presenting, problem-solving, negotiating, directing, standardizing, and reinforcing when working with teachers-behaviors not typically associated with managers and rarely fully addressed in traditional leadership preparation programs. Reeves (2004) also pointed out that leadership at its best means that school leaders examine their holistic accountability for the welfare of teachers and students. 
Halpern and Lubar (2003) emphasized that explicit values that guide one's actions are necessary for effective leaders and that true leadership goes far beyond just accomplishing tasks, but rather includes motivating, inspiring, and energizing complete organizations. An in-depth review of eighty surveys from school administrators with a minimum of five years of experience revealed that successful leadership preparation programs utilized instructors who were experienced practitioners, facilitated networking opportunities among students, relied upon strong relationships between students and mentors, and promoted professional development opportunities for students (Michael \& Young, 2006). Educational leadership programs must take more responsibility for providing opportunities for program participants to develop their capacity to lead using their value systems. In particular, study of the educational leadership preparation program at Delta State University (DSU) found certain exemplary aspects.

\section{The School Leadership Study}

Developing Successful Principals was a major research effort that seeks to address the questions: What are the essential elements of good leadership? What are the features of effective pre-service and in-service leadership development programs? What governance and financial policies are needed to sustain good programs? Commissioned by The Wallace Foundation and undertaken by the Stanford Educational Leadership Institute in conjunction with The Finance Project, the study examined hundreds of program across the United States and selected eight pre- and in-service program models that address key issues in developing strong leaders for additional in-depth review...

Other schools' programs offered important components such as internships, cohort structures, close partnerships with local school districts, and integrated curricula. However, few that we examined put these pieces together as comprehensively or as consistently well as the Educational Leadership Program at Delta State University. Delta State provides a full-time internship experience, financial support so teachers can leave the classroom to spend a year preparing to be a principal, and a passion for developing school leaders capable of transforming the poor, mostly rural, schools in the region...

Our analysis revealed several exemplary program attributes. These included the rigorous selection process, financial support for candidates, an intensive internship experience, integrated curriculum, and mentoring and cohort relationships. These attributes help define the program and shed an interesting light on the impact of the program on its graduates." (LaPointe, Davis, \& Cohen, 2007, p. ii, 1, 32)

\section{SIX DEFINING FEATURES}

The Educational Leadership Program at DSU contains many features that are consistent with important theories and practices in the field of administrator preparation and that are found with increasing frequency among programs across the country. However, the DSU program is distinguished by the depth, consistency, and thoughtfulness with which it prepares practice-ready school leaders. It does this through:

1. The implementation of a rigorous and highly selective admissions process.

2. The development of core values and skills framed around leadership for powerful teaching and learning.

3. The cultivation of self-reflection and ethical behaviors.

4. The application of problem-based and authentic learning experiences aligned with relevant theoretical foundations.

5. The development of leaders oriented toward organizational change and renewal.

6. The cultivation of strong partnerships with regional school districts. (LaPointe, Davis, \& Cohen, 2007, p. 25) 


\section{DEVELOPMENT OF THE PROGRAM}

Developing school leaders who are flexible, courageous, and capable of effectively leading schools in the changing educational landscape is of supreme importance. With increasing criticism of school leaders and the programs that prepare them, gleaning a better understanding of how to build strong educational leadership programs is vital to the institutions charged with this responsibility. Housed within the Thad Cochran Center for Rural School Leadership and Research, the M.Ed. full-time educational leadership program at Delta State University was implemented to provide the region with strong school leaders in an effort to fully realize the DSU mission of positively impacting the Delta. The program was developed through the collaborative efforts of local and state leaders with assistance from a national advisory board of leadership experts. Initial development was based on the recommendations of a task force established by the state superintendent of education to address the need for change in leadership preparation. The program was first implemented in the 1998-99 school year and has been refined annually as part of a continuous improvement cycle in the College of Education.

\section{SELECTION PROCESS}

Rather than the traditional method of self-selection, the Educational Leadership program at DSU is predominately populated by students who have been nominated by the school districts in which they teach. This process allows students to receive financial assistance from their districts through the Mississippi Administrator Sabbatical Program which provides a base salary. In return, graduates who have been sponsored by their districts commit to serve a minimum of five years as repayment for the financial assistance. Some students receive a scholarship provided through a federal grant which requires that students agree to serve a minimum of three years in a Delta area school district as a principal or assistant principal. Only if space remains and individuals successfully complete the rigorous selection process, may a self-selected student become a participant in the program.

The application portfolio requires that candidates take the Graduate Record Examination; submit a writing sample, a resume, and academic transcripts; and provide letters of recommendation and verification of a minimum of three years of teaching experience. After initial screening, applicants participate in a structured interview with a selection team. Enrollment is limited to twenty participants to ensure that internship site visitation and extensive individual feedback may be completed appropriately.

\section{INNOVATIVE SCHEDULING}

The program includes a 14 month/48 credit hour period of study beginning in June of each year and concluding in July of the following year. Students attend class every day for the first summer term, as they prepare to spend 12 weeks during each of three internships in the fall and spring semesters. All students have internship assignments in diverse elementary, middle, and high school settings and are not permitted to return to their "home" schools for the internship experiences. Additionally, students complete a one or two-week internship in a district central office to allow exposure to the global view of educational leadership. During internships, students return to campus weekly for Wednesday seminars which focus on problem-solving and presentation of specific content. Between internships, students attend a two-week session on campus for intense instructional seminars. Final oncampus study takes place during the summer term after the internship year.

\section{INTERNSHIP}

The internship experience is the cornerstone of the full-time educational leadership program. Students are paired with successful school principals who function as their mentors in creating an environment where the student actually functions in the role of an assistant principal. This supervised training ground gives students the same type of opportunity afforded physicians and other professionals as they are allowed to actually practice their craft under the watchful eyes of advanced professionals. The mentoring, faculty and peer feedback, and self-reflection provide the basis for sound personal leadership development for students as they progress through their internship experiences. Data from a national study suggest: 
Corroborating the evidence gathered at the school sites, the survey results revealed several important differences between the responses of the graduates from the Delta State administrative credential program and those from other Mississippi programs and from a national sample of school administrators. The survey findings consist of both frequency analyses and statistical tests to determine if group responses on the survey items were significantly different. In most of the cases reported below, the differences between DSU and non-DSU respondents reflect significance at the .05 level of confidence or higher. Such findings suggest that several important characteristics of the Delta State program are truly unique and distinct from those found in the comparison groups. Survey responses by DSU graduates reflected the perceptions of the program expressed by DSU candidates and recent graduates who were interviewed during site visits in November 2004 and April 2005. The following analysis is organized primarily around several important themes that became apparent both through our review of research and our DSU program site visits (LaPointe, Davis, \& Cohen, 2007, p. 27).

Figure 2 summarizes responses of Delta State University graduates as compared to other Mississippi and national principals related to the internship (LaPointe, Darling-Hammond, \& Meyerson, 2007, p. 20).

Figure 2: "To complete my internship"

(1-Not at all, 3-Somewhat; 5-To a great extent)

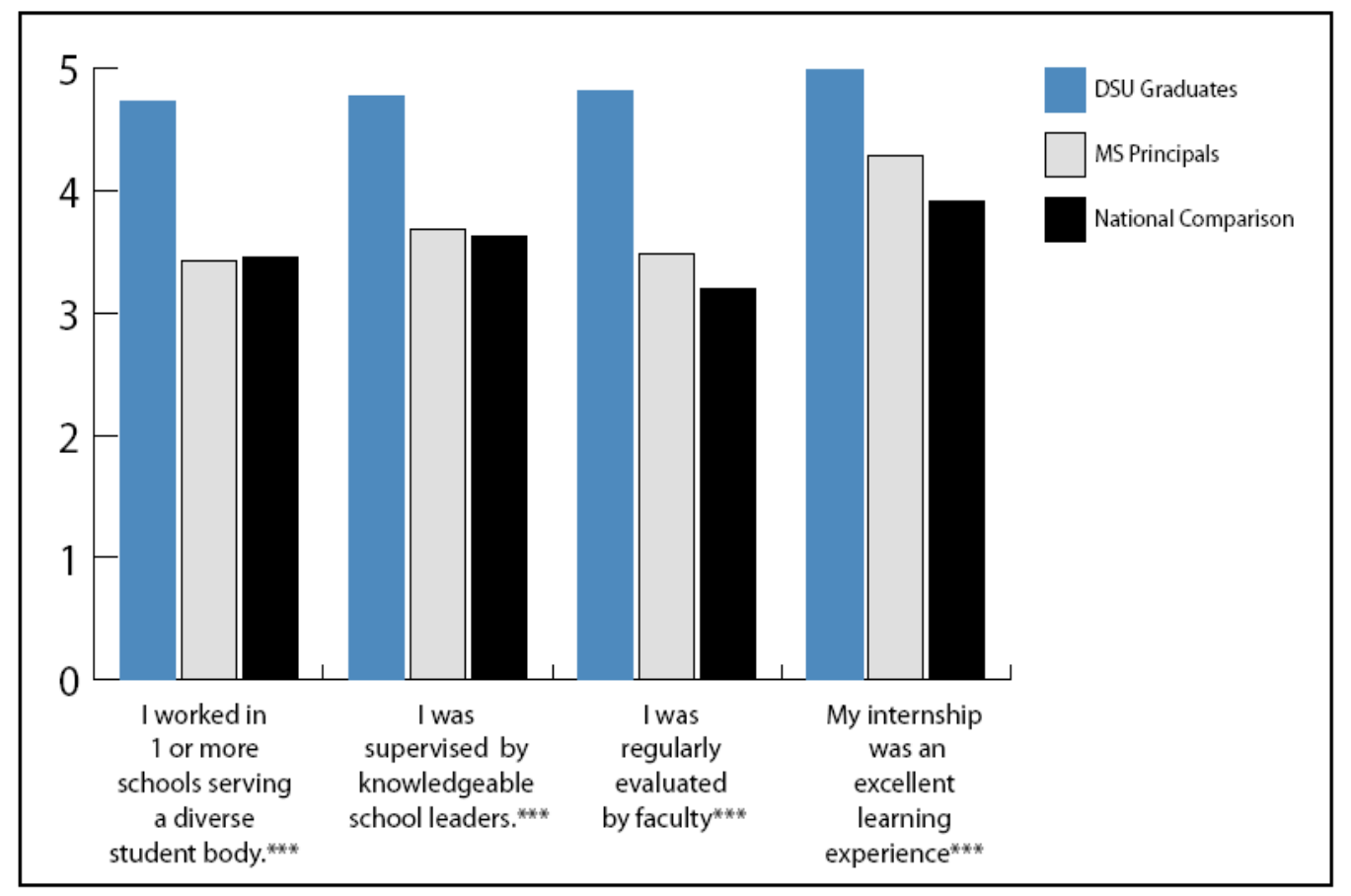

T-Tests of mean differences: ${ }^{*} \mathrm{p}<.05 ;{ }^{* *} \mathrm{p}<.01 ;{ }^{* * *} \mathrm{p}<.001$

\section{MODEL OF INSTRUCTION}

By utilizing a cohort model that employs full-time internship experiences and intense class sessions focusing on reflection and problem-based learning, prospective principals leave the program with the knowledge, skills, and values/beliefs that research indicates produce effective results in schools. Building on three guiding anchors--teaching and learning, organizational effectiveness, \& school and community-- the instructors in the program serve as facilitators who engage students in meaningful dialogue around the problems and issues experienced during their school and central office internships. Rather than traditional courses, content is integrated to maximize connectivity of topics important to effective leadership. While the essentials of law, finance, curriculum 
development and other more traditional topics are included in the rigorous curriculum, each knowledge area is connected to the specific requirements found in the daily operation of schools. Ethical decision-making, human relations skills, organizational capacity, and instructional leadership are interwoven within the curriculum and instructional processes used. The instructional model also provides frequent and specific individual feedback sessions with peers, faculty, and mentors. Program participants exit DSU with a solid knowledge/experiential base, as well as a group of critical friends who provide on-going support after program completion. Program graduates have continued a $100 \%$ pass rate on the School Leaders Licensure Assessment from the program's inception to the current graduates. Figure 3 shows how DSU graduates, other Mississippi principals and national principals compare according to how they spend their time at work (LaPointe, Darling-Hammond, \& Meyerson, 2007, p. 21).

\section{Figure 3: Principal Practices: How often do you engage in the following activities (1-Not at all, 3-Somewhat; 5-To a great extent)}

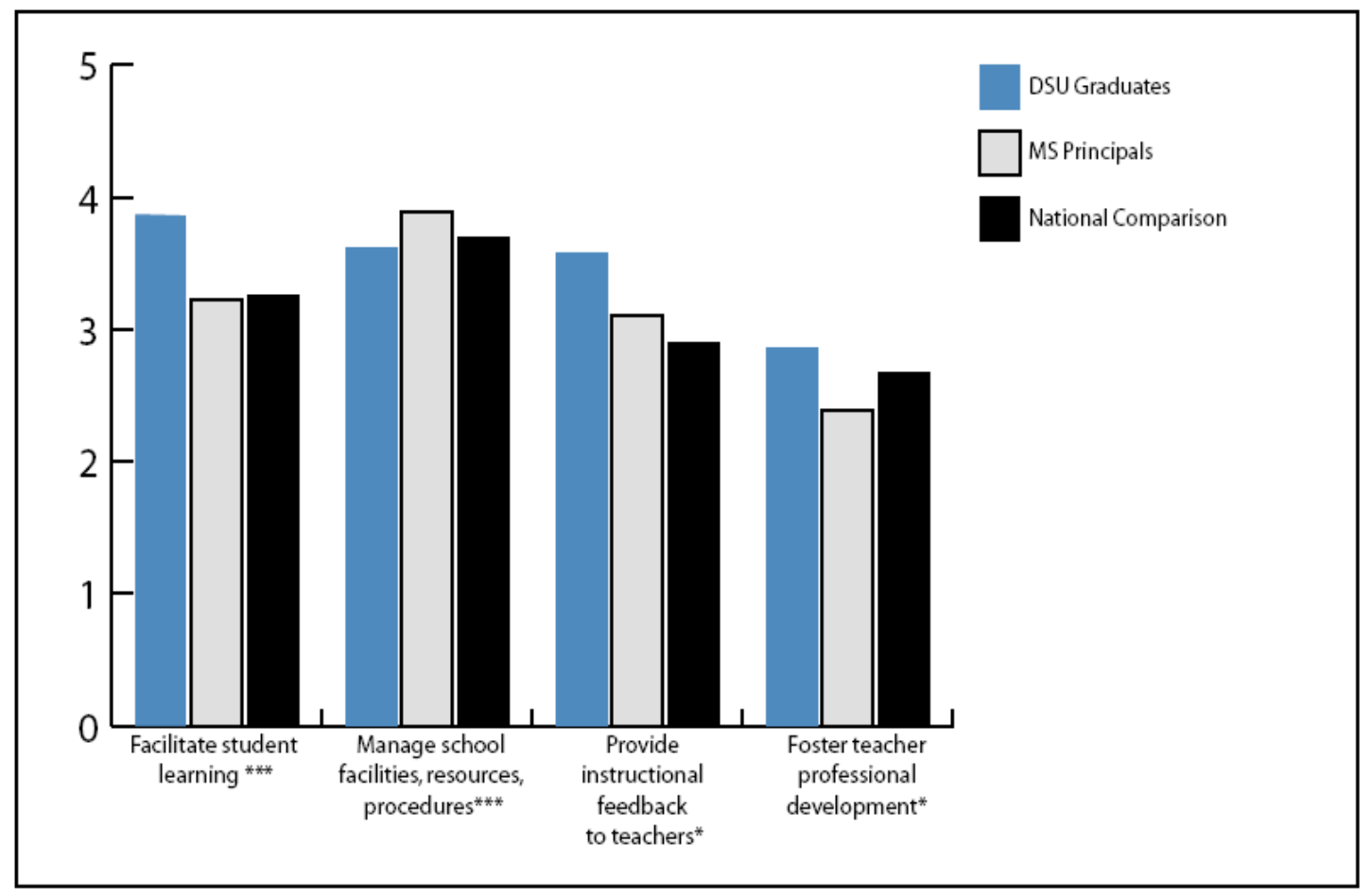

T-Tests of mean differences: ${ }^{*} \mathrm{p}<.05 ;{ }^{* *} \mathrm{p}<.01 ;{ }^{* * *} \mathrm{p}<.001$

The following quotes from program participants, graduates, and employers of graduates are typical of the feedback surrounding this program.

- $\quad$ The program participants that we send return to our district as outstanding principals and assistant principals who are head and shoulders above other traditionally-prepared educators.--Mr. Charlie Alexander, Asst. Superintendent, DeSoto County Schools

- $\quad$ The demand for quality administrators is met through your nationally recognized program.--The Honorable Haley Barbour, Governor, State of Mississippi

- $\quad$ The program gave me an opportunity to become involved in a strong, extensive, educational atmosphere paired with the opportunity to explore, research, and discover the true meaning of being an instructional leader.--Bonnie Horton, Central Office-Humphreys County 
- $\quad$ During the 14 months with Delta State, I feel I was challenged to think differently about the role of the school administrator. By helping teachers become more effective in their classrooms..., I believe I can positively affect more children as they work through the learning process.--Leslie Busby, Asst. Principal-S. Panola Schools

- $\quad$ The on-site hands-on training that I received has enhanced my performance as an administrator by helping me to utilize research-based best practices, analyze and utilize data to make decisions, function as an effective change agent, become proactive in problem-solving, provide ongoing professional development correlated to needs, act as a supervisor of instruction....involve all stakeholders to increase student achievement.--Ms. Glenda Shedd, Principal, Carver Lower Elementary, Indianola

- $\quad$ I believe the graduates of the sabbatical program at Delta State are able to transfer theory into practice more readily and efficiently than those of us from more traditional programs...the transition into a leadership position is shorter and greatly enhanced...--Mr. Henry Phillips, Jr., Supt. of West Bolivar Schools

- $\quad$ The program provides in one year what any other form of preparation would take years to accomplish.-Dr. Arthur Cartlidge, Former Supt. of Greenville Schools

\section{ADDITIONAL SURVEY FINDINGS}

The program faculty also conduct follow up surveys with graduates and employers each year using the Educational Leadership Preparation Program Questionnaire (ELPPQ). The instrument may be found in Appendix A. Below are the results for the 2006 year. Each question on the survey is measured on a Likert scale of 1 to 5 . A 5 represents Above expected at this level; 4 represents Average for experience; 3 represents Below expected at this level; 2 represents Need extreme improvement; and a 1 represents Unable to answer. Table 1 displays the descriptive statistics for the data analysis and Table 2 displays the frequency distribution of data. Table 2 indicates the percentage of responses on the Likert scale for each question.

ELPPQ Aggregated Data - 2006

Thad Cochran Center for Rural School Leadership and Research

\begin{tabular}{|c|c|c|c|c|c|}
\hline \multicolumn{7}{|c|}{ Table 1 } \\
\hline \multicolumn{7}{|c|}{ Descriptive Statistics } \\
\hline Question 1 & N & Minimum & Maximum & Mean & Std. Deviation \\
Question 2 & 42 & 3.00 & 5.00 & 4.7381 & .49680 \\
Question 3 & 39 & 2.00 & 5.00 & 4.7179 & .60475 \\
Question 4 & 40 & 2.00 & 5.00 & 4.6500 & .62224 \\
Question 5 & 42 & 4.00 & 5.00 & 4.7143 & .45723 \\
Question 6 & 41 & 4.00 & 5.00 & 4.8049 & .40122 \\
Question 7 & 41 & 4.00 & 5.00 & 4.7073 & .46065 \\
Question 8 & 41 & 4.00 & 5.00 & 4.7317 & .44857 \\
Valid N & 39 & 4.00 & 5.00 & 4.8205 & .38878 \\
(listwise) & 39 & & & & \\
\hline
\end{tabular}




\begin{tabular}{|c|c|c|c|c|c|c|}
\hline \multicolumn{7}{|c|}{ Table 2} \\
\hline \multicolumn{7}{|c|}{ Aggregated Data Frequency Distribution } \\
\hline \multirow{3}{*}{ Question } & \multicolumn{6}{|c|}{ Response Percent to Each Question } \\
\hline & & Likert 5 & Likert 4 & Likert 3 & Likert 2 & Likert 1 \\
\hline & $\mathrm{n}$ & $\begin{array}{c}\text { Above Expected } \\
\text { At This Level }\end{array}$ & $\begin{array}{l}\text { Average For } \\
\text { Experience }\end{array}$ & $\begin{array}{c}\text { Below Expected At } \\
\text { This Level }\end{array}$ & $\begin{array}{l}\text { Need Extreme } \\
\text { Improve-Ment }\end{array}$ & $\begin{array}{c}\text { Unable To } \\
\text { Answer }\end{array}$ \\
\hline 1 & 42 & 76.2 & 21.4 & 2.4 & & \\
\hline 2 & 39 & 76.9 & 20.5 & & 2.6 & \\
\hline 3 & 40 & 70.0 & 27.5 & & 2.5 & \\
\hline 4 & 42 & 71.4 & 28.6 & & & \\
\hline 5 & 41 & 80.5 & 19.5 & & & \\
\hline 6 & 41 & 70.7 & 29.3 & & & \\
\hline 7 & 41 & 73.2 & 26.8 & & & \\
\hline 8 & 39 & 82.1 & 17.9 & & & \\
\hline
\end{tabular}

Both from data collected nationally and locally, the program graduates and their employers confirm that the ideals and practices of this model appear to be successfully preparing future school leaders who may indeed make a positive impact on education in this area. Hopefully, as others learn more about models that are working, this circle of influence can spread around the country to help P-12 students receive quality education through their principals.

\section{BENEFITS}

The DSU leadership program model builds upon a broad understanding of the craft of leadership. Specific model components support the role of school leadership as a catalyst for bringing about social change for both school and community through ethical, value-added leadership strategies. Support for programs which challenge the status-quo is needed if appropriate social change is to be sustained.

Current school leadership support from legislative bodies, state departments of education, national educational organizations, and the public in general is meager. Programs illustrative of appropriate revitalization need additional exposure so they are broadly recognized as a means of contributing to positive social change.

The program has ensured that a diverse group of participants was selected for each cohort. Variety in relation to gender, race, geography, and district demographics ensures that a broad range of perspectives is present during discussion seminars. Additionally, internship assignments are made in diverse settings for each cohort member rather than allowing internships to occur in self-selected home school sites as has been the case in most traditional leadership preparation programs.

Recognizing that school leadership should be an opportunity available to a broad range of individuals, recruitment from diverse school settings has been a primary effort within the participant selection process. The result of this effort has been the inclusion of leadership students who view their purpose as being to enhance the lives of all students and the community at-large. Students who exit the program seem totally committed to that purpose. Over time, this dedicated effort can significantly improve schools, communities, and the society in which we live. Lessons from exemplary programs may help other educational administration programs as they strive to develop and support school leaders who can shape schools into vibrant learning communities. 


\section{REFERENCES}

1. Bennis, W. (1994). On becoming a leader. Massachusetts: Perseus Publishing.

2. $\quad$ Bolman, L. G., \& Deal, T.E. (1997). Reframing organizations: artistry, choice, and leadership. (2 ${ }^{\text {nd }}$ ed.) San Francisco: Jossey-Bass.

3. Caruso, D. R., \& Salovey, P. (2004). The emotionally intelligent manager. San Francisco: Jossey-Bass.

4. $\quad$ Drucker, P. F. (1999). Management challenges for the $21^{\text {st }}$ century. New York: Harper Business.

5. Glatter, R. (2006). Leadership and organization in education: Time for a re-orientation? School Leadership and Management, 26(1,) 69-83.

6. Glickman, C. D. (2002). Leadership for learning: How to help Teachers Succeed. Alexandria, VA: Association for Supervision and Curriculum Development.

7. Halpern, B. L., \& Lubar, K. (2003). Leadership Presence. New York: Gotham Books.

8. LaPointe, M., Darling-Hammond, L., \& Meyerson, D. (Eds.). (2007). Preparing school leaders for a changing world: Case studies of exemplary programs. Stanford, CA: Stanford University, Stanford Educational Leadership Institute.

9. LaPointe, M., Davis, S., \& Cohen, C. (2007). School leadership study: Developing successful principals (Case study series: Principal preparation at Delta State University - A bold strategy to improve practice). Stanford, CA: Stanford University, Stanford Educational Leadership Institute.

10. Michael, C. N., \& Young, N. D. (2006). Preparing the next generation of school administrators: Advice from veteran leaders. (ERIC Document Reproduction Service No. ED491530)

11. Reeves, D. B. (2004). Accountability for Learning: How Teachers and School Leaders Can Take Charge. Alexandria, VA: Association for Supervision and Curriculum Development.

12. Sousa, D. A. (2003). The Leadership Brain: How to Lead Today's Schools More Effectively. Thousand Oaks, CA: Corwin Press. 


\section{NOTES}

